\section{Effects of Budgetary Participation on Managerial Attitudes, Satisfaction, and Managerial Performance}

\author{
Efeitos da Participação Orçamentária em Atitudes Gerenciais, Satisfação e \\ Desempenho Gerencial
}

\author{
Vinícius Costa da Silva Zonatto \\ Juliana Constâncio Nascimento ${ }^{2}$ 를 \\ Micheli Aparecida Lunardi ${ }^{2}$ \\ Larissa Degenhart ${ }^{1}$
}

\section{ABSTRACT}

Objective: the purpose of this paper is to investigate the effects of budget participation on management attitudes, job satisfaction, and managerial performance of controllers of Brazilian companies. Methodology: a descriptive, survey, and quantitative research was conducted from a sample of 316 individuals with budgetary responsibility. Results: the results indicated that budgetary participation directly and positively influences managerial attitudes toward budgeting, job satisfaction, and controllers' performance in budget activities. Indirect relationships revealed that managerial attitudes toward budget and job satisfaction mediate the relationship between budgetary participation and managerial performance. It was found that budgetary participation positively influences the level of use of the budget for the purposes of performance evaluation and contributes to the development of budgetary knowledge of managers. Conclusion: the budgetary participation is responsible for important consequences on the attitudes and performance of these professionals. From a managerial point of view, it is essential to understand how the budgeting process can influence the attitudes, satisfaction, and performance of controllers in the budgeting context, since after this understanding, the managerial functions can be improved.

Keywords: budgetary participation; managerial attitudes; job satisfaction; managerial performance.

JEL Code: L25, M54, J28.

'Universidade Federal de Santa Maria, Programa de Pós-graduação em Ciências Contábeis, Santa Maria, RS, Brazil.

${ }^{2}$ Universidade Regional de Blumenau, Programa de Pós-graduação em Ciências Contábeis, Blumenau, SC, Brazil.

Cite as: Zonatto, V. C. da S., Nascimento, J. C., Lunardi, M. A., \& Degenhart, L. (2020). Effects of budgetary participation on managerial attitudes, satisfaction, and managerial performance. Revista de Administração Contemporânea, 24(6), 532-549. https://doi.org/10.1590/1982-7849rac2020200047

\section{RESUMO}

Objetivo: a proposta deste artigo é investigar os efeitos da participação orçamentária nas atitudes gerenciais, satisfação no trabalho e no desempenho gerencial de controllers de empresas brasileiras. Metodologia: realizou-se uma pesquisa descritiva, de levantamento e quantitativa, a partir de uma amostra de 316 indivíduos com responsabilidades orçamentárias. Resultados: os resultados indicaram que a participação orçamentária influencia diretamente e positivamente as atitudes gerenciais em relação ao orçamento, a satisfação no trabalho e o desempenho dos controllers em atividades orçamentárias. As relações indiretas revelaram que as atitudes gerenciais em relação ao orçamento e a satisfação no trabalho medeiam a relação entre a participação orçamentária e o desempenho gerencial. Verificou-se que a participação orçamentária influencia positivamente o nível de uso do orçamento para fins de avaliação de desempenho e contribui para o desenvolvimento do conhecimento orçamentário dos gerentes. Conclusão: a participação orçamentária é responsável por importantes consequências nas atitudes e no desempenho desses profissionais. Do ponto de vista gerencial, é primordial compreender como o processo orçamentário pode influenciar as atitudes, a satisfação e o desempenho dos controllers no contexto orçamentário, pois, após este entendimento, as funções gerenciais podem ser aprimoradas.

Palavras-chave: participação orçamentária; atitudes gerenciais; satisfação no trabalho; desempenho gerencial.

\# of invited reviewers until the decision

\begin{tabular}{|c|c|c|c|c|c|c|c|c|c|}
\hline & 1 & 2 & 3 & 4 & 5 & 6 & 7 & 8 & 9 \\
\hline $1^{\text {st }}$ round & $\stackrel{8}{2}$ & (x) & $x$ & (x) & 2 & & & & \\
\hline $2^{\text {nd }}$ round & $\stackrel{0}{2}$ & & & & & & & & \\
\hline
\end{tabular}

Editor-in-chief: Wesley Mendes-Da-Silva (Fundação Getulio Vargas, EAESP, Brazil) Reviewers: Antonio Zanin (Universidade Comunitária da Região de Chapecó, Brazil) Flávio Carvalho (Universidade Federal de São Carlos, Brazil) 1 


\section{INTRODUCTION}

The budget is a tool used for management control (Frezatti, 2009), and in addition to the control function, it has the ability to influence the attitudes and behaviors of individuals at work (Merchant, 1981; Covaleski, Evans III, Luft, \& Shields, 2007). For Kenis (1979), the budget is not only a financial plan that sets cost and revenue targets for accountability centers, but also a device for control, coordination, communication, and performance appraisal.

For Milani (1975), the budget is one of many administrative activities that can highlight certain types of human reactions. In this sense, the budget has the ability to encompass and influence the participation of individuals in setting budget objectives (Milani, 1975; Young, 1985; Shields \& Shields, 1998; Subramaniam \& Ashkanasy, 2001; Jacomossi, Schlup, \& Zonatto, 2018; Lunardi, Zonatto, \& Nascimento, 2020).

Behavioral studies on budget participation were driven by Argyris (1952), who provided qualitative evidence that budgeting can affect employees' mental state and behavior (Santos, Lavarda, \& Marcello, 2014; Derfuss, 2009). Based on the findings of Argyris (1952) and on the adoption of theories of organizational and social psychology, the research seeks to explain how budget participation can affect budget and managerial performance through its influence on subordinate cognition and motivation (Shields \& Shields, 1998; Derfuss, 2009; Degenhart, Lunardi, \& Zonatto, 2019; Lunardi, Zonatto, \& Nascimento, 2020).

Some authors treat budget participation as a potentiator of individuals' performance at work (Argyris, 1952; Kenis, 1979; Mia, 1988; Nouri \& Parker, 1998; Zonatto, 2014; Zonatto, Weber, \& Nascimento, 2019). However, other authors have found controversial results in this relationship between budget participation and work performance (Derfuss, 2009; 2016; Byrne \& Damon, 2008; WongOn-Wing, Guo, \& Lui, 2010; Dani, Zonatto, \& Diehl, 2017).

The controversies found in the results can be explained by Covaleski, Evans, Luft, and Shields (2007), and the results between budgetary participation and performance may be influenced by individuals' mental or cognitive states. Bandura (1977) explains that human action may respond to the divergences found regarding behavior and the development of individuals in a context of social interaction.

According to Bandura (1977), human development and action are determined by the interactionist effect of cognitive and personal factors, behavioral factors, and environmental constraints, which is termed in Cognitive Social Theory as cognitive social factors. Thus, there is a possible explanation for the conflicting results found in the literature for the direct relationship between budget participation and the performance of individuals in the workplace.

According to Argyris (1952), Kenis (1979), Nouri and Parker (1998), Zonatto (2014), Degenhart, Lunardi, and Zonatto (2019), and Lunardi, Zonatto, and Nascimento (2020), the individual participant in the budgeting process enhances his managerial performance and positive attitudes (Merchant, 2007; Kyj \& Parker, 2008). Merchant (2007) and Mia (1988) point out that studies linking budget participation with managerial attitudes show that the cognitive effects of managerial attitude tend to be more favorable in organizations that use budgeting as part of their management control strategy. In addition, budgetary participation can influence individual satisfaction in the work environment, which will lead to higher performance (Dewar \& Werbel, 1979; Brownell, 1982; Dunk, 1992; Kyj \& Parker, 2008).

Regarding the effects of managerial attitudes, job satisfaction, and managerial performance in the budget context in the behavioral accounting, the results of previous studies have also been controversial. While Milani (1975) found a negative relationship between managerial attitude and managerial performance, when measured as an intervening variable, Mia (1988) found a positive relationship. The same is true for job satisfaction. Chenhall and Brownell (1988) found significance between budgetary participation and job satisfaction, but not with performance. Chong, Eggleton, and Leong (2005) identified a positive and significant association between satisfaction and performance. Dunk (1992) verified a positive and statistically significant relationship between the interaction between budgetary participation and the managerial level in relation to job satisfaction.

It is observed that the interactions between individuals, adoption and use of management control systems (in this case, the budget), as well as the variables addressed, are complex and difficult to understand, which reinforces the need for further studies on the theme. Likewise, there is no evidence of the joint effects of budget participation, managerial attitudes, and job satisfaction on managerial performance, a theoretical gap that stimulates this research.

It is understood that the cognitive, motivational, and realization value effects of budget participation on managerial performance are better understood when evaluating the interactionist effects advocated in Bandura's Cognitive Social Theory (1977) with interdependent variables, present in the budget context, which can 
influence the relationship between participation and performance. Given the above, the main objective of this research is to evaluate the effects of budget participation on managerial attitudes, job satisfaction, and managerial performance.

The justification of the research is to understand the social and cognitive factors that influence managerial performance in the budget context, as well as the influence of attitudes on the relationship between budgetary participation and managerial performance. Thus, the behavioral approach in the accounting is able to identify which interactionist factors impact managerial performance (Zonatto, 2014). Since cognitive social factors are characterized as interactionist by Bandura (1977), it appears that such an approach may explain the relationship between the budget process and performance. This theoretical approach has been little used in accounting, the theoretical contribution of this research.

Although budgets are often criticized by researchers and users of the tool, they are widely used in most organizations (Libby \& Lindsay, 2010) and analyzed through the participation of individuals in budgeting processes. Budgetary participation has been studied most often in international literature (Lavarda \& Fank, 2014). In Brazil, behavioral research associated with budget participation and managerial performance is scarce, which makes the application of this study relevant (Santos et al., 2014; Dani et al., 2017; Zonatto et al., 2019).

The results of this study demonstrate that job performance can be affected by budgetary participation indirectly and directly. It is noticed that the performance of subordinates can be potentiated by mediating variables, in this case, managerial attitudes and individual satisfaction, which corroborates the theoretical assumptions presented by Bandura (1977) and the cognitive, motivational, and relationship value effects of budgetary participation. Thus, it can be inferred that the participation of subordinates in the budgeting process drives greater satisfaction and better managerial attitudes, which will lead to higher performance of subordinates in the work environment.

As contributions, the study demonstrates the importance of the research for the business environment. Budgetary participation can contribute to the improvement of management processes, as well as the improvement of the work environment, which tends to positively impact the performance of employees in the organization (Zonatto \& Lavarda, 2013; Lunardi et al., 2020). In this sense, budget participation motivates and assists subordinates in their job performance
(Shields \& Shields, 1998; Subramaniam \& Mia, 2001; Jermias \& Yigit, 2013). Financial indicators present facts that have already occurred. However, human indicators enable the manager to predict the future performance of the organization (Avey, Numnicht, \& Pigeon, 2010). Thus, the evidence of the effects of the adoption and use of control instruments on human behavior at work constitutes the theoretical and practical contribution of the study, since it enables organizations and managers to understand under what conditions the adoption of budget management practices (participatory) will produce positive effects on individuals at work.

\section{ANALYSIS MODEL AND RESEARCH HYPOTHESES}

\section{Budgetary participation and managerial performance}

Business budgeting as a control tool has become an important tool for organizations, among other reasons, because of the need to maintain a balance between financial forecasts and the results actually achieved by department managers (Santos et al., 2014). According to Hannan, Rankin, and Towry (2010), budgeting can play a crucial role in planning, control, and in resource allocation and coordination of organizations' activities.

The budget presents the meaning that the organization intends to address for a certain period, and allows the evaluation of the results of managers and the organization (Frezatti, 2009). The budget can be defined in many ways and involves various hierarchical levels; it can be defined from top to bottom, bottom to top, or in the participatory form (Zainuddin, Yahya, Kader Ali, \& Abuenniran, 2008). Participation is defined when managers are involved in setting budgetary goals and objectives (Milani, 1975; Young, 1985; Shields \& Shields, 1998; Subramaniam \& Ashkanasy, 2001).

Among the many reasons the literature lists for budgetary participation, the following stand out: the opportunity for information sharing (Kyj \& Parker, 2008), motivation (Merchant, 2007; Kyj \& Parker, 2008) and employee satisfaction (Kyj \& Parker, 2008), organizational justice perception communication (Kyj \& Parker, 2008), open communication and employee interaction (Lavarda \& Almeida, 2013), increased positive attitudes (Merchant, 2007), and increased work performance (Argyris, 1952; Kenis, 1979; Mia, 1988; Nouri \& Parker, 1998; Zonatto, 2014; Jacomossi et al., 2018; Degenhart et al., 2019; Lunardi et al., 2020).

Given this behavioral approach, budgeting has been analyzed as a means to influence the behavior of the individuals involved (Birnberg, Luft, 
\& Shields, 2007; Covaleski, Evans, Luft, \& Shields 2007; Zonatto, 2014). Thus, evidence is found that higher levels of budgetary participation are related to higher levels of managerial performance (Argyris, 1952; Kenis, 1979; Merchant, 1981; Brownell, 1982; Brownell \& McInnes, 1986; Dunk, 1992; Lau, Low, \& Eggleton, 1997; Nouri \& Parker, 1998; Chong \& Chong, 2002; Parker \& Kyj, 2006; Chong \& Johnson, 2007).

However, it is necessary to consider the complexity of human cognition, which in the budget context may differently influence the performance of individuals at work and at least partially explains the conflicting results still found for the direct analysis of this relationship (Derfuss, 2016; Dani et al., 2017). Considering the prevailing evidence presented in the literature, it is expected in this research that under conditions of greater budgetary participation, higher levels of managerial performance are perceived in individuals. Thus, the first hypothesis of this research assumes that:

H1. There is a positive and significant relationship between budgetary participation and managerial performance.

\section{Budgetary participation and managerial attitudes}

According to the behavioral approach in accounting, budgetary participation can influence an individual's cognitions and motivations (Chong, Eggleton, \& Leong, 2005). Related to budgetary participation, cognitive effects refer to the availability of information that the manager has to identify his responsibilities at work. Already the motivational effects deal with work effort and identification of the manager with the organization. Achievement value indicates the individual's satisfaction with the work, and the feeling of being part of the organization. Thus, the motivational and achievement value effects are related to the attitudes of individuals at work (Chong et al., 2005).

In this research, attitudes are attributed to thoughts or feelings of the individual. Thus, it evaluates how the individual would wish to behave in relation to a defined attitude object (Rodrigues, 1986). To assess managers' attitudes at work, the variables related to work-related managerial attitude (Merchant, 2007) and job satisfaction (Dewar \& Werbel, 1979) are used.

Work-related attitudes are conceptualized by Milani (1975) as the tendency, judgment, or thinking of the individual about his work. By analyzing the attitudes of managers under two aspects - work-related attitudes and organizationrelated attitudes - , Milani (1975) identified that there is a positive relationship between budgetary participation and attitudes, both workplace and company-related attitudes. The positive association between budgetary participation and managerial attitudes was also identified by Kenis (1979).

In this context, considering the evidence, it is expected that under conditions of greater budgetary participation, higher levels of managerial attitudes will be identified. Thus, the second hypothesis of this research assumes that:

H2. There is a positive and significant relationship between budgetary participation and managerial attitudes at work.

By studying budgetary participation and its behavioral aspects, participation was identified as an influential element in the behavior of individuals at work, producing effects classified by Chong et al. (2005) as cognitive, motivational, and achievement value. Job satisfaction was also investigated on this behavioral aspect with budgetary participation, being defined by Schermerhorn, Hunt, and Osborn (2007, p. 93) as "the degree to which individuals feel positively or negatively in relation to their job. It is an attitude, or an emotional response, to work tasks as well as the physical and social conditions of the workplace."

Studies that investigated the relationship between budgetary participation and job satisfaction have also presented conflicting results, which reinforces the need to investigate the interactions between these and other variables of the budget context. A positive relationship was found by Brownell (1983), Frucot and Shearon (1991), and Chong et al. (2005). Dunk (1992) found a positive relationship between budgetary participation and managerial level in relation to job satisfaction. The study by Brownell (1982), which addressed the superior's style of assessment and budgetary participation, did not identify any relationship with job satisfaction.

In this investigation, considering the predominant evidence found in the literature, it is expected that higher levels of budgetary participation will identify higher levels of job satisfaction. Thus, the third hypothesis of this research assumes that:

H3. There is a positive and significant relationship between budgetary participation and job satisfaction.

\section{Indirect effects of budgetary participation on managerial performance}

Budgetary participation and its influence on managerial performance have been directly analyzed and presented divergent results (Derfuss, 2016). Thus, it is necessary to investigate their effects on 
performance from a broader perspective, identifying this influence, directly and indirectly, observing the mediating effects of intervening variables (Dani et al., 2017; Zonatto et al., 2019).

Given the indirect effects of budgetary participation on managerial performance, management attitudes are observed as potentially intervening variables that impact performance. It is understood that the manager's performance in his work activities is directly impacted by his managerial attitudes. With regard to job satisfaction, it may also be able to impact performance.

In the psychological approach to budgeting, it is admitted that it can have an impact on the behavior and cognition of individuals, consequently influencing their actions at work through motivation, commitment, satisfaction, and job performance (Birnberg et al., 2007).

Under this approach and with the proposal to test behavioral variables as actors in the relationship between budgetary participation and performance, Chong (2002) did not identify the relationship between budgetary participation and performance when tested directly. However, when analyzing the relationship mediated by paper ambiguity, the negative relationship was observed.

Mia (1988) observed a positive relationship when analyzing managerial attitudes intermediating budgetary participation with performance. Another behavioral variable that was identified as intervening in the relationship between budgetary participation and managerial performance was the organizational commitment in the study by Nouri and Parker (1998).

As can be seen, individuals may respond differently to the environmental impacts in which they operate, which may provide an explanation for the distinct results found for the direct relationship between budgetary participation and performance, as well as the mediating effects of variables intervening in this relationship. As Bandura (1977) explains, this is because individuals differ in their psychobiological capacities and there are those who cannot learn and develop.

In this context, considering this evidence, it is expected in this research that in higher levels of budgetary participation, higher levels of managerial performance are identified, when mediated by managerial attitudes and job satisfaction. Thus, two research hypotheses were developed to test the mediating effects of work attitudes, segregated into managerial attitude and job satisfaction, in which it is assumed that:

H4. Managerial attitude mediates the relationship between budgetary participation and managerial performance; and

H5. Job satisfaction mediates the relationship between budgetary participation and managerial performance.

This study, based on the evidence shown above, proposes the links between the variables selected for the research: budgetary participation, job satisfaction, managerial attitudes, and managerial performance. Figure 1 presents the theoretical model analyzed.

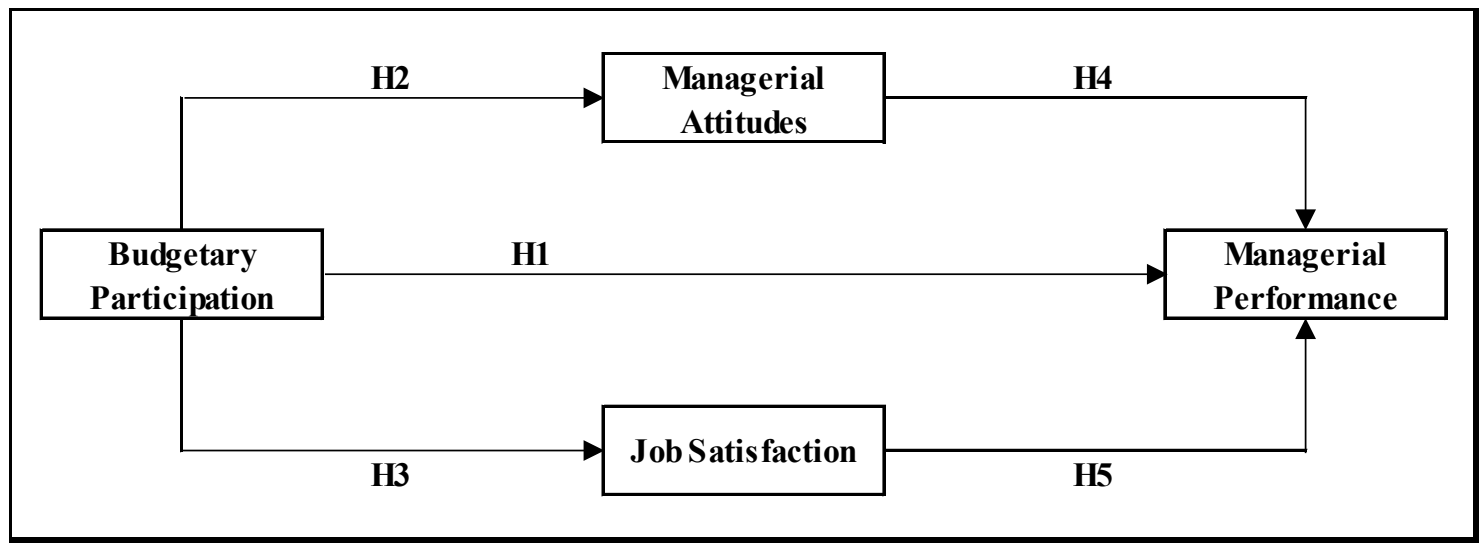

Figure 1. Theoretical analysis model.

Source: elabored by the authors.

\section{METHODOLOGICAL PROCEDURES}

The methodology used in this research is characterized as a descriptive study, conducted through survey and quantitative data approach.
The survey included 316 controllers from Brazilian companies with budgetary responsibility. The controllers were contacted with the help of the LinkedIn professional relationship network. 
For the definition of the sample, individuals with budgetary responsibility who had such a function were contacted from November 2016 to February 2017. Initially, an invitation was requested asking individuals to participate in the research. After the invitation was accepted, the questionnaire was sent to the controllers who showed interest in participating in the research. 1985 invitations were sent; of these, 852 accepted the invitation to answer the research instrument. Thus, the research sample had the voluntary participation of 316 individuals with budgetary responsibility from different organizations based in the country.

The choice of the controller was justified by Schmidt and Santos (2006), because this professional has a broad view of the company, and can perform different activities within the organization, ranging from the coordination of the accounting sector and its reports to participation at the company's strategic level (Ribeiro, Lunkes, Schnorrenberger, \& Gasparetto, 2011). Thus, regardless of the level allocated, operational, managerial, or strategic, the controller will always be performing the management function (Oro, Beuren, \& Carpes, 2014).

In order to define the minimum number of respondents needed to conduct the research, the recommendations of Hair, Babin, Money and Samouel (2005) were adopted. According to the authors, the use of structural equation modeling for data analysis requires a minimum of five respondents per indicator evaluated in each structural research model. A greater number than this was reached in this investigation.

The instrument used for data collection is a questionnaire composed of 26 objective multiplechoice questions, which was elaborated from the constructs presented in Table 1, observing their original measurement scales.

Table 1. Constructs, operationalization, and definition.

\begin{tabular}{|c|c|c|c|}
\hline Variables & Definition & Questions/Scale & Authors \\
\hline $\begin{array}{l}\text { Budgetary } \\
\text { participation } \\
\text { (PB) }\end{array}$ & $\begin{array}{l}\text { Identifies the level of involvement of the individual in the } \\
\text { budgeting process of his organization. }\end{array}$ & $\begin{array}{l}6 \text { questions } \\
\text { Likert Scale } 7 \\
\quad \text { points }\end{array}$ & Milani (1975) \\
\hline $\begin{array}{l}\text { Managerial } \\
\text { attitudes } \\
\text { (MA) }\end{array}$ & $\begin{array}{l}\text { Attitudes are attributed to the individual's thoughts or feelings, } \\
\text { as he would wish to behave toward a defined attitudinal object } \\
\text { (Rodrigues, 1986). }\end{array}$ & $\begin{array}{l}5 \text { questions } \\
\text { Likert Scale } 5 \\
\text { points }\end{array}$ & Merchant (2007) \\
\hline $\begin{array}{l}\text { Job satisfaction } \\
\qquad(\mathrm{ST})\end{array}$ & $\begin{array}{l}\text { It is an attitude toward work activities, the structural and social } \\
\text { conditions of the work environment (Schermerhorn et al., 2007). }\end{array}$ & $\begin{array}{l}6 \text { questions } \\
\text { Likert Scale } 7 \\
\text { points }\end{array}$ & $\begin{array}{l}\text { Dewar \& Werbel } \\
\quad(1979)\end{array}$ \\
\hline $\begin{array}{l}\text { Managerial } \\
\text { performance } \\
\quad(D G)\end{array}$ & $\begin{array}{l}\text { Measured with a self-assessment scale, this variable identifies } \\
\text { how budget-responsive controllers evaluate their performance. }\end{array}$ & $\begin{array}{l}9 \text { questions } \\
\text { Likert Scale } 7 \\
\text { points }\end{array}$ & $\begin{array}{l}\text { Mahoney, Jerdee, \& } \\
\text { Carroll }(1963,1965)\end{array}$ \\
\hline
\end{tabular}

Note. Source: elabored by the authors.

The collected data were tabulated in spreadsheets and later imported for the SPSS ${ }^{\circledR}$ software for statistical treatment. Initially, we proceeded to the evaluation of missing data, in which all 316 questionnaires were kept, as they were properly completed.

The following step was the statistical analysis, which was performed using descriptive statistics and exploratory factor analysis to validate the measurement constructs, according to procedures recommended by Hair et al. (2005). The validation was based on the observation of the grouping of the indicators in their respective measurement constructs, the factorial load of at least 0.60 , the significance of the Bartlett sphericity test and the KMO test, as well as the total explained variance of the constructs.
After the evaluation and purification of the constructs, the data were analyzed descriptively, verifying real interval and theoretical range, mean, standard deviation, asymmetry, kurtosis. Subsequently, Cronbach's alpha, composite reliability and extracted mean variance coefficients were analyzed to measure the quality of each construct.

Finally, the discriminant analysis of the validated measurement constructs was performed for the research, according to the analysis criteria recommended by Bagozzi and Phillips (1982), and the analysis of the relationships investigated through the modeling of structural equations with the aid of $\mathrm{AMOS}^{\circledR}$ software. The results found are presented below. 


\section{PRESENTATION AND ANALYSIS OF RESULTS}

\section{Characterization of respondents}

To characterize the controllers that make up the sample investigated in the study, their gender, age, and hierarchical level in their organization were verified. Table 2 presents the synthesis of the results related to gender and age.

Among the 316 controllers participating in the research, there was a predominance of male professionals (277). The predominant age range among these professionals is between 31 and 40 years (45.57\%), $87.97 \%$ are over 31 years, and only 4 professionals are over 60 years. The level of academic education that predominates among the respondents is the lato sensu graduate (specialization) $(69.94 \%, 221)$. Only 45 have a master's degree (14.24\%) and 5 have a doctorate degree (1.58\%).

In order to better understand their performance in the budget context of these organizations, we also sought to verify the hierarchical level of respondents' role and the level of budget utilization for performance evaluation purposes in the organization in which they operate, as well as their level of knowledge of the budget, routines, and budgeting processes. The synthesis of these results is presented in Table 3 .

Table 2. Description of gender and age range of the surveyed controllers.

\begin{tabular}{ccc}
\hline Gender & Absolute frequency & Relative frequency \\
\hline Men & 277 & $87.66 \%$ \\
Woman & 39 & $12.34 \%$ \\
Totals & 316 & $100 \%$ \\
\hline Age range & Absolute frequency & Relative frequency \\
\hline From 21 to 30 years old & 34 & $10.76 \%$ \\
\hline From 31 to 40 years old & 144 & $45.57 \%$ \\
\hline From 41 to 50 years old & 92 & $29.11 \%$ \\
From 51 to 60 years old & 42 & $13.29 \%$ \\
Above 61 years old & 4 & $1.27 \%$ \\
Totals & 316 & $100 \%$ \\
\hline
\end{tabular}

Note. Source: research data.

Table 3. Hierarchical level of function, budget use for performance appraisal, and budget knowledge.

\begin{tabular}{|c|c|c|c|c|c|c|c|}
\hline Considering the scale presented & TR & $\mathrm{RR}$ & Average & Med. & SD & Asym. & Kurt. \\
\hline Hierarchical level of function in the organization & $1-7$ & $2-7$ & 5.83 & 6.00 & 0.95 & -0.810 & 0.937 \\
\hline $\begin{array}{l}\text { Budget utilization level for organizational performance } \\
\text { appraisal purposes }\end{array}$ & $1-7$ & $1-7$ & 5.83 & 6.00 & 1.35 & -1.429 & 1.974 \\
\hline Knowledge level in relation to budget & $1-7$ & $2-7$ & 6.52 & 7.00 & 0.79 & -2.471 & 8.649 \\
\hline $\begin{array}{l}\text { Level of knowledge regarding budget routines and } \\
\text { processes }\end{array}$ & $1-7$ & $2-7$ & 6.49 & 7.00 & 0.82 & -2.237 & 7.601 \\
\hline
\end{tabular}

Note. Legend: TR: Theoretical range; RR: Real range; Med.: Median; SD: Standard deviation; Asym.: Asymmetry; Kurt.: Kurtosis. Source: research data.

As can be seen from the results presented in Table 3, it was identified that no respondent considered the hierarchical level of his function totally low (1). The average of the answers obtained is high (5.86), with a standard deviation of 0.95 , which indicates low data variance around the mean. Thus, most respondents occupy a high hierarchical level in the organizations in which they operate.

The same is true for performance budgeting, where the average response rate was also 5.83, indicating a high level of budget utilization for performance appraisal in most of these organizations. However, unlike the previous question, in this case there were some reports that in certain organizations the level of use for this purpose is low. These results can be corroborated with the highest standard deviation observed (1.35) in the answers analyzed in this question.

When conducting an analysis around their own budget knowledge, most of the surveyed controllers reported having a high level of knowledge about the topic (mean 6.52, standard deviation 0.79) and about 
knowledge about routines and budgetary processes (average 6.49, standard deviation 0.82). These results suggest that budget activities are present among the attributions developed by the research controllers participating in their organizations.

In this context, observing the general characterization aspects analyzed in this research phase, it can be inferred that the professionals who perform the function of the controller, controllers managers, or controllers coordinators in these organizations are predominantly male, under the age of fifty years, with a high hierarchical level of his role in the organization, using the budget for performance appraisal purposes and with a high level of knowledge about budgetary routines and processes. The results of the factor analysis and descriptive statistics of the theoretical constructs used for this investigation are presented below.

\section{Factorial and descriptive data analysis}

Factorial analysis is intended to "define the inherent structure between the analysis variables" (Hair, Babin, Money, \& Samouel, 2005, p. 102). For all constructs used in this research, which have already been used by other researchers, individual validation analyzes were performed, so that their predictive ability to measure can be validated. Initially, the following tests were performed to evaluate the analyzed constructs: Kaiser-MeyerOlkin (KMO) sample adequacy measure, Bartlett's sphericity test, total variance explained, factor load and commonalities. The reliability of each construct was investigated by Cronbach's alpha coefficient. The results presented in Table 4 refer to the final constructs already suitable for analysis.

Table 4. Results of exploratory factor analysis and descriptive statistics of the constructs.

\begin{tabular}{|c|c|c|c|c|c|c|c|c|c|c|c|c|c|}
\hline Var. & $\mathrm{CA}$ & KMO & BST & TVE & Ind. & $\mathrm{TR}$ & $\mathrm{RR}$ & AV & SD & AS & $\mathrm{KT}$ & FL & Com. \\
\hline \multirow{6}{*}{$\begin{array}{c}\text { Budgetary } \\
\text { participation } \\
(\mathrm{BP})\end{array}$} & \multirow{6}{*}{0.853} & \multirow{6}{*}{0.835} & \multirow{6}{*}{$\begin{array}{l}865.23 \\
(0.000)^{*}\end{array}$} & \multirow{6}{*}{$60.06 \%$} & BP01 & $1-7$ & $1-7$ & 6.49 & 1.07 & -2.78 & 8.71 & 0.81 & 0.66 \\
\hline & & & & & BP02 & $1-7$ & $1-7$ & 5.75 & 1.43 & -1.20 & 1.05 & 0.61 & 0.37 \\
\hline & & & & & ВР03 & $1-7$ & $1-7$ & 6.44 & 0.99 & -2.50 & 7.92 & 0.79 & 0.63 \\
\hline & & & & & ВР04 & $1-7$ & $1-7$ & 6.10 & 1.24 & -1.72 & 3.20 & 0.80 & 0.64 \\
\hline & & & & & BP05 & $1-7$ & $1-7$ & 6.42 & 0.97 & -2.58 & 8.91 & 0.83 & 0,69 \\
\hline & & & & & BP06 & $1-7$ & $1-7$ & 5.97 & 1.31 & -1.63 & 2.63 & 0.76 & 0.58 \\
\hline \multirow{5}{*}{$\begin{array}{c}\text { Managerial } \\
\text { attitudes (MA) }\end{array}$} & \multirow{5}{*}{0.856} & \multirow{5}{*}{0.836} & \multirow{5}{*}{$\begin{array}{l}727.14 \\
(0.000)^{*}\end{array}$} & \multirow{5}{*}{$65.08 \%$} & MA01 & $1-5$ & $1-5$ & 4.57 & 0.64 & -1.53 & 2.74 & 0.81 & 0.66 \\
\hline & & & & & MA02 & $1-5$ & $1-5$ & 4.15 & 0.92 & -1.02 & 0.70 & 0.73 & 0.53 \\
\hline & & & & & MA03 & $1-5$ & $1-5$ & 4.25 & 0.86 & -1.11 & 1.03 & 0.79 & 0.63 \\
\hline & & & & & MA04 & $1-5$ & $1-5$ & 4.44 & 0.76 & -1.61 & 3.35 & 0.83 & 0.70 \\
\hline & & & & & MA05 & $1-5$ & $1-5$ & 4.44 & 0.71 & -1.37 & 2.57 & 0.84 & 0.72 \\
\hline \multirow{6}{*}{$\begin{array}{c}\text { Job } \\
\text { satisfaction } \\
\text { (JS) }\end{array}$} & \multirow{6}{*}{0.881} & \multirow{6}{*}{0.816} & \multirow{6}{*}{$\begin{array}{l}1246.24 \\
(0.000)^{*}\end{array}$} & \multirow{6}{*}{$63.45 \%$} & JS01 & $1-7$ & $3-7$ & 6.02 & 0.93 & -0.84 & 0.46 & 0.72 & 0.53 \\
\hline & & & & & JS02 & $1-7$ & $1-7$ & 5.70 & 1.30 & -1.15 & 1.49 & 0.71 & 0.51 \\
\hline & & & & & JS03 & $1-7$ & $1-7$ & 5.77 & 1.17 & -1.23 & 1.83 & 0.77 & 0.59 \\
\hline & & & & & JS04 & $1-7$ & $1-7$ & 5.88 & 1.12 & -1.26 & 1.99 & 0.83 & 0.70 \\
\hline & & & & & JS05 & $1-7$ & $1-7$ & 5.69 & 1.21 & -1.04 & 1.27 & 0.86 & 0.74 \\
\hline & & & & & JS06 & $1-7$ & $1-7$ & 5.85 & 1.07 & -0.88 & 0.82 & 0.84 & 0.71 \\
\hline \multirow{9}{*}{$\begin{array}{c}\text { Managerial } \\
\text { performance } \\
(\mathrm{MP})\end{array}$} & \multirow{9}{*}{0.886} & \multirow{9}{*}{0.893} & \multirow{9}{*}{$\begin{array}{l}1315.29 \\
(0.000)^{*}\end{array}$} & \multirow{9}{*}{$53.84 \%$} & MP01 & $1-7$ & $1-7$ & 5.92 & 0.93 & -1.04 & 2.03 & 0.70 & 0.49 \\
\hline & & & & & MP02 & $1-7$ & $1-7$ & 5.93 & 0.95 & -1.20 & 3.04 & 0.75 & 0.56 \\
\hline & & & & & MP03 & $1-7$ & $3-7$ & 6.02 & 0.91 & -0.68 & -0.21 & 0.67 & 0.46 \\
\hline & & & & & MP04 & $1-7$ & $2-7$ & 5.75 & 1.00 & -0.63 & 0.00 & 0.81 & 0.66 \\
\hline & & & & & MP05 & $1-7$ & $1-7$ & 6.08 & 0.97 & -1.31 & 2.48 & 0.77 & 0.60 \\
\hline & & & & & MP06 & $1-7$ & $1-7$ & 5.84 & 1.07 & -1.19 & 2.22 & 0.80 & 0.64 \\
\hline & & & & & MP07 & $1-7$ & $1-7$ & 5.61 & 1.17 & -1.05 & 1.59 & 0.68 & 0.46 \\
\hline & & & & & MP08 & $1-7$ & $1-7$ & 5.29 & 1.42 & -0.81 & 0.31 & 0.71 & 0.50 \\
\hline & & & & & MP09 & $1-7$ & $4-7$ & 5.89 & 0.74 & -0.42 & 0.11 & 0.66 & 0.44 \\
\hline
\end{tabular}

Note. Legend: Var.: Variable; CA: Cronbach's alpha; BST: Bartlett's sphericity test; TVE: Total variance explained; Ind.: Indicator; TR: Theoretical range; RR: Real range; AV: Average; SD: Standard deviation; AS: Asymmetry; KT: Kurtosis; FL: Factorial load; Com.: Commonality. Source: Research data. 
The results of the exploratory factor analysis shown in Table 4 reached Cronbach's alpha coefficients expected, Bartlett's sphericity KMO test presented statistical significance, and the total variance explained values greater than 0.50 in all cases. Regarding the factor loading of the indicators of each measurement construct, no variable was excluded, as all indicators were grouped in their factor and presented the loads higher than the minimum recommended by Hair et al. (2005)

The descriptive analysis of the budgetary participation construct also presents answers in all its indicators, indicating both maximum agreement levels (7) and maximum disagreement (1). In this case, these results reveal that not all responding controllers perceive their participation as active in the budget processes of the companies in which they operate. They also reveal that in some organizations, their contribution to resource allocation occurs when budgeting is not considered by the supervisor.

Overall, the average indicators for the budgetary participation construct were high - however, with a higher standard deviation, which reveals greater dispersion among the responses obtained. The lowest average and highest standard deviation among indicators of this construct are found in variable PO02 (mean 5.750, standard deviation 1.433), which investigates whether superiors provide information when the budget is revised. Thus, it can be inferred that most of the research participants participating in the research are fully involved in budgeting, as well as having the autonomy to express opinions or suggestions regarding the budget.

In the variables of the construction of managerial attitudes in relation to the budget, it can be observed that all indicators reached minimum and maximum answers in the scale used. Considering the maximum value of the interval (5), the variables presented high means, indicating high agreement between most of the answers obtained. To the satisfaction of the controllers at work, it is clear that the theoretical range covered the scale from 1 to 7 , with only the actual range of variable ST01 different among the variables that make up this construct. The highest level of agreement in this construct is found in variable ST01, which measures the satisfaction that the work provides controllers, starting at the real interval at 3, with the highest mean 6.022 (ST01) and the lowest standard deviation.

Job satisfaction can result in personal satisfaction, pride in working for the organization, a sense of belonging, and work can also be rewarding. When testing this construct with individuals responsible for controllership, the evidence indicated great personal satisfaction caused by the work. However, despite a high average, ST05, which represents the satisfaction caused by budgetary participation, was less frequent. Thus, it can be inferred that most of the surveyed controllers are satisfied with their work, but budgetary participation may not cause such high satisfaction.

This evidence reinforces the importance of investigating the joint effects of the selected variables for the research so that it can be better inferred about the direct and indirect effects of budgetary participation on managerial performance, whether or not mediated by managerial attitudes and job satisfaction.

Analyzing the results identified for the indicators related to the self-assessment of the controller's managerial performance, on a scale of 1 for below-average performance and 7 for aboveaverage performance, responses are heterogeneous among the performance activities evaluated in this construct. These results show that not all professionals participating in the research rate their managerial performance in such activities as above average.

They also reveal that these professionals can develop distinct activities in their organizations, due to the characteristics of their functions and attributions in their work activities, which is in agreement with the evidence of Schmidt and Santos (2006) and Ribeiro, Lunkes, Schnorrenberger, and Gasparetto (2011). Even the controller performing the management function (Oro et al., 2014), his performance in work activities will not be uniform in all work activities (Zonatto, 2014).

These findings reinforce the opportunity to investigate the relationships proposed in this research, as the distinct responses obtained among participants may reveal under what conditions existing interactions between budgetary participation, managerial attitudes, and job satisfaction can positively influence performance. In summary, considering all the results found in the descriptive statistical analysis of the theoretical constructs investigated in this research stage, it is clear that the levels of budget participation differ among part of the professionals participating in the research. The same is true for managerial attitudes, satisfaction levels, and managerial performance at work. Therefore, it is appropriate to investigate the relationships between these variables, which is presented below.

Analysis of the effects of budgetary participation on managerial attitudes, job satisfaction, and managerial performance

After defining the theoretical models of analysis and conducting statistical validation tests of the constructs, the discriminant validity of the structural model tested was analyzed, as recommended by Bagozzi and Phillips (1982). The discriminant validity of the measurement constructs that make up the structural model was assessed, followed by the analysis of the influence of budgetary participation on managerial attitudes, job satisfaction, and managerial performance of controllers, as established in the theoretical analysis 
model elaborated for the study (Figure 1), so that the general objective and research hypotheses established for the investigation can be answered. The path estimation results of the measurement model are presented in Figure 2.

As identified in Figure 2, there is a positive relationship between budgetary participation and managerial attitudes $(\lambda=0.62)$ of the controllers studied, as well as budgetary participation and job satisfaction $(\lambda=0.42)$. The path between budgetary participation and managerial performance $(\lambda=0.20)$ is the weakest among the relationships studied in this model. However, it still has a positive and significant relationship, indicating that budgetary participation has a weak direct relationship with managerial performance. Relationships between managerial attitudes and managerial performance $(\chi=0.25)$ and job satisfaction and managerial performance $(\lambda=0.32)$ also indicated a positive and significant relationship. The indices of adjustment of the model for measuring the influence of budgetary participation on attitudes, satisfaction, and managerial performance of controllers are listed in Table 5.

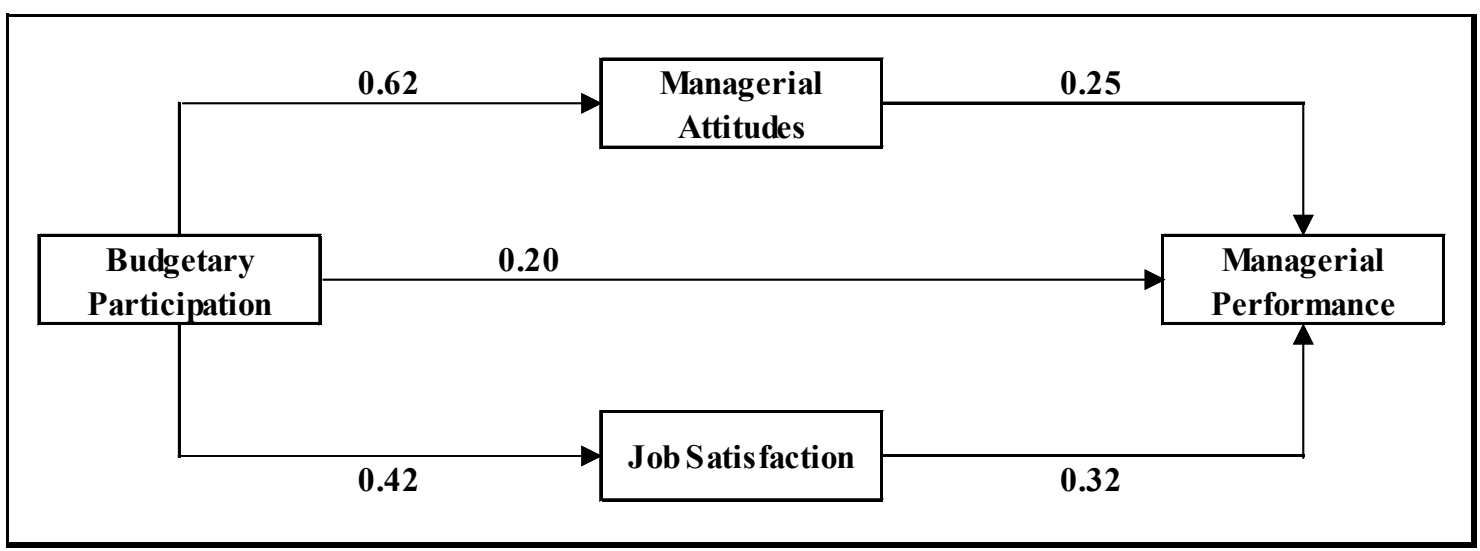

Figure 2. Estimates of ways to measure the effects of budgetary participation on managerial attitudes, job satisfaction, and managerial performance.

Source: research data.

Table 5. Adjustment indices of the model for measuring the effects of budgetary participation on managerial attitudes, job satisfaction, and managerial performance.

\begin{tabular}{|c|c|c|c|}
\hline Adjustment measures & Recommended value & Reference & Level found \\
\hline Qui $^{2}$ & - & - & 1045.478 \\
\hline Degrees of freedom - DF & - & - & 295 \\
\hline $\mathrm{Qui}^{2} / \mathrm{GL}$ & $<5$ & Hair et al. (2009) & 3.544 \\
\hline$P$ & $\mathrm{p}<0.05$ & Hair et al. (2009) & 0.000 \\
\hline GFI & $>0$ and $<1$, better closer to 1 & Hair et al. (2009) & 0.798 \\
\hline AGFI & $>0$ and $<1$, better closer to 1 & Hair et al. (2009) & 0.759 \\
\hline RMSEA & $>0.10$ & Hair et al. (2009) & 0.090 \\
\hline TLI & $>0$ and $<1$, better closer to 1 & Hair et al. (2009) & 0.817 \\
\hline NFI & $>0$ and $<1$, better closer to 1 & Hair et al. (2009) & 0.784 \\
\hline CFI & $>0$ and $<1$, better closer to 1 & Hair et al. (2009) & 0.834 \\
\hline
\end{tabular}

Note. Source: research data.

The results presented in Table 5 show that the proposed measurement model for analyzing the effects of budgetary participation on attitudes, satisfaction, and performance presents acceptable levels, indicating the predictive validity of the proposed model. The adjustment index of the model presented a value of 1045.47 with a significance level of 0.000 . The root mean square error of approximation (RMSEA) index was at the expected level (0.090). The comparative adjustment index (CFI) resulted in 0.834, approaching the expected (0.90). The same occurred with GFI (0.798), AGFI (0.759), TLI (0.817), and NFI (0.784). Table 6 presents the standardized coefficients and significance of the relationships tested in the model. 
Table 6. Standardized coefficients and significance of relationships of the model for measuring the effects of budgetary participation on managerial attitudes, job satisfaction, and managerial performance.

\begin{tabular}{cccccccc}
\hline \multicolumn{2}{c}{ Structural paths } & & Estimate & EP & t-values & P & $\begin{array}{c}\text { Standardized } \\
\text { coefficient }\end{array}$ \\
\hline MA & $\leftarrow$ & BP & 1.000 & - & - & - & 0.623 \\
JS & $\leftarrow$ & BP & 0.562 & 0.102 & 5.505 & $* * *$ & 0.389 \\
MP & $\leftarrow$ & BP & 0.303 & 0.104 & 2.900 & 0.004 & 0.200 \\
MP & $\leftarrow$ & MA & 0.240 & 0.074 & 3.232 & 0.001 & 0.174 \\
MP & $\leftarrow$ & JS & 0.365 & 0.078 & 4.689 & $* * *$ & 0.325 \\
\hline
\end{tabular}

Note. Legend: BP: Budgetary participation; MA: Managerial attitudes; JS: Job satisfaction; MP: Managerial performance. Source: research data.

As shown in Table 6, the relationship between $\mathrm{MA} \leftarrow \mathrm{BP}$ had its initial values set at 1.000 . Therefore, the t-values of this relationship were not calculated. In the other relationships tested, all p-values were higher than recommended by Hair et al. (2005), indicating that the relationships are statistically significant in the model. The relation between $\mathrm{MA} \leftarrow \mathrm{BP}$ presented a coefficient of explanation $\left(\mathrm{R}^{2}\right)$ of 0.389 , that is, the budgetary participation has an explanatory power of $39 \%$ on managerial attitudes.

To verify the relationships tested, five hypotheses were specified so that the relationship between MP $\leftarrow$ BP is included in hypothesis H1 There is a positive and significant relationship between budgetary participation and managerial performance.

According to the results presented in Table 6, the relationship between budgetary participation and managerial performance is positive and significant, thus confirming hypothesis $\mathrm{H} 1$. However, it is observed that among all tested relationships with managerial performance, the budget share had the lowest standardized coefficient (0.200). This result corroborates the findings of the research by Lau, Low, and Eggleton (1997), Nouri and Parker (1998), and Zonatto and Lavarda (2013) who also identified the positive relationship between budgetary participation and managerial performance. They also differ from the findings of Dunk (1989) and Brownell and Dunk (1991), who identified negative outcomes for these relationships.

For the MA $\leftarrow$ BP relationship, hypothesis $\mathrm{H} 2-$ There is a positive and significant relationship between budgetary participation and managerial attitudes at work, the relationship found is also positive and significant.

Thus, it can be stated that budgetary participation influences the managerial attitudes of controllers of companies operating in Brazil.

Managerial attitudes when influenced by budget enable controllers to be better managers, more flexible, more innovative, use better production methods, and have the ability to monitor their management results. Managerial attitudes enhanced by budgetary participation can positively influence job performance (Mia, 1988). In this study, the controllers investigated less often believe that budgeting can make individuals more flexible and more innovative. However, the evidence found indicates that controllers consistently believe that budgeting makes them better managers.

Some works corroborate these findings. Milani (1975) verified the relationship between workrelated attitudes and company-related attitudes and budgetary participation, also finding evidence of a positive relationship between these variables. The results indicated that both attitudes are positively related to budgetary participation. Regarding the specific variable of managerial attitudes, Mia (1988) found a positive correlation between managerial attitudes and budgetary participation.

Similarly, the result found by Merchant (2007) identified a relationship between budgetary participation and managerial attitudes, called by the author the "feeling of the utility of the budget." However, it was partly related because the author segregated budgetary participation into three levels: influence on budget planning, personal involvement, and time spent on budgeting. The variable sentiment of the utility of the budget or managerial attitude toward the budget correlates with the time spent with the budget.

Regarding the relationship between job satisfaction and budgetary participation, it can be seen from the data in Table 6 that the JS $\leftarrow$ BP ratio was identified as positive, with an explanation coefficient of 0.174 , i.e., the influence of budgetary participation on job satisfaction is explained by a coefficient of $17 \%$. Thus, we can confirm the positive relationship tested by the hypothesis H3 - There is a positive and significant relationship between budgetary participation and job satisfaction.

Corroborating this result, Brownell (1983) identified that both high and low levels of budgetary participation positively affect job satisfaction. 
Dunk (1992) also identified a positive relationship between the interaction of budgetary participation with management level and job satisfaction. Despite this, the opposite result was found by Chong (2002), who did not identify the direct relationship between budgetary participation and job satisfaction. However, when the relationship was moderated by ambiguity of roles, job satisfaction showed a significant and negative relationship.

These results suggest that other intervening variables may influence this relationship, which reinforces the need for further studies, in order to better understand the (direct and indirect) effects of participation in performance, as well as the direct effects of participation in intervening variables.

Regarding the mediation of the managerial attitude variable in the relationship between budgetary participation and managerial performance, according to the standardized coefficients found, $\mathrm{MA} \leftarrow \mathrm{BP}$ $(0.623)$ and $\mathrm{MP} \leftarrow \mathrm{MA}(0.255)$, it can be stated that there is a positive and significant relationship between the variables analyzed, confirming hypothesis $\mathrm{H} 4-$ The managerial attitude mediates the relationship between budgetary participation and managerial performance.

These variables were also measured by Mia (1988), so that managerial attitudes and performance were not correlated in that investigation when directly analyzed. However, the analysis of the relationship between budgetary participation and managerial performance was positively related when the managerial attitudes variable mediated them, thus corroborating the results found in this research.

These results corroborate the indirect effects of participation on performance (Derfuss, 2016; Dani et al., 2017), and the need to investigate the effects of participation on performance from a broader theoretical perspective (Zonatto et al., 2019), so that one can understand under what conditions participatory budgeting results in better managerial performance.

Also, regarding the tested relationships between budgetary participation and managerial performance, observing the effects of potentially intervening variables, a positive and significant relationship was also confirmed when this relationship is mediated by job satisfaction through the standardized coefficients of the JS $\leftarrow$ BP (0.417) and MP $\leftarrow$ JS (0.325) ratios. Agreeing with Covaleski et al. (2007) in the statement that the budget impacts the behavior and cognition of the individual by various means, among them satisfaction, can confirm the hypothesis H5 - Job satisfaction mediates the relationship between budgetary participation and managerial performance.

Therefore, it is inferred that managerial performance is affected by the joint effect of budgetary participation, managerial attitudes, and job satisfaction of controllers.

Confirming hypothesis $\mathrm{H} 5$, the result of this research corroborates parts of the study by Frucot and Shearon (1991), as the authors identified the increase in performance of individuals with budgetary participation, and satisfaction was only increased in high manager's level. Since all respondents in this research were controllers and reported having a high hierarchical level of their function in the organization in which they operate, the joint effect of the variables was identified.

These results converge with the theoretical precepts established by cognitive social theory. Cognitive and personal factors tend to influence the individual's responses in the environment (Bandura, 1977), in this case in the budgetary context. This interaction allows evaluating the conditions under which the individual will make an effort to reach the goals and objectives established in the budget context, resulting in influence on their performance (Zonatto, 2014).

Moreover, the results found indicate that when the controller has the largest budget share and realizes that this share contributes to the budget process in his unit, he also tends to have proactive managerial attitudes toward the budget, making them better managers, more flexible and innovative. Participation also increases the satisfaction of these individuals at work, generating satisfaction and personal fulfillment. These results are also reflected in improved job performance, so that the controller is better able to set goals, guide and lead subordinates, achieving better managerial performance under the budget context.

Looking at the manager's budgetary participation, there is a high performance in his work activities (Argyris, 1952; Zonatto, 2014), as this budgetary participation can increase the individual's commitment to work (Chong et al., 2005), motivation, and positive attitudes (Merchant, 2007), and can therefore positively impact business performance (Karakoc \& Ozer, 2016). Thus, it is identified the importance of observing the effects of the adoption and use of management control instruments, such as the budget, on human behavior at work, since human action will directly reflect on the company's results.

\section{Complementary analysis}

Based on this evidence, we sought to analyze whether the variables used to characterize respondents are able to influence such relationships, providing explanations for any differences in the sample analyzed. Table 7 shows the results of the complementary analysis performed. 
Table 7. Results of the complementary analysis.

\begin{tabular}{|c|c|c|c|c|c|c|}
\hline & Variables & & BP & MA & JS & MP \\
\hline \multirow{6}{*}{ 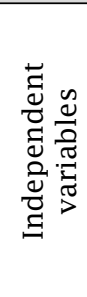 } & Hierarchical level of function in the organization & \multirow{6}{*}{ 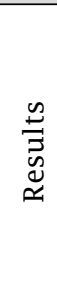 } & 0.059 & $0.116 * *$ & $0.103 * *$ & $0.116^{*}$ \\
\hline & Budget utilization level for organizational performance appraisal purposes & & $0.197^{*}$ & $0.233^{*}$ & $0.202 *$ & $0.290 *$ \\
\hline & Knowledge level in relation to budget & & $0.256^{*}$ & 0.017 & -0.120 & -0.133 \\
\hline & Level of knowledge regarding budget routines and processes & & $0.161^{*}$ & 0.059 & $0.261 *$ & $0.354 *$ \\
\hline & Age & & $-0.102 *$ & -0.051 & 0.024 & 0.044 \\
\hline & Genre & & $0.090 * *$ & $-0.106^{* *}$ & -0.078 & -0.174 \\
\hline \multicolumn{3}{|l|}{$\mathrm{R}^{2}$} & 0.288 & 0,124 & 0.135 & 0.286 \\
\hline \multicolumn{3}{|c|}{ Sig. Anova } & 0.000 & 0.000 & 0.000 & 0.000 \\
\hline
\end{tabular}

Note. Legend: BP: Budgetary participation; MA: Managerial attitudes; JS: Job satisfaction; MP: Managerial performance. No out of the sample tests were performed to verify the robustness and stability of the simulated model. * Significance at the $5 \%$ level. ** Significance at the level of $10 \%$. Source: research data.

The results found reveal that in a participatory budgetary configuration, the level of use of the budget for purposes of performance evaluation in the organization is higher, compared to those that do not adopt this configuration of budgetary management. Lau and Buckland (2001) emphasize that when budgetary objectives are used to assess subordinates, they seek to participate in the budget definition process, which may impact their performance.

The levels of knowledge in relation to the budget, and in relation to the budget routines and processes of the organization in which they operate, are also positively associated with participatory budgeting. These results suggest that budgetary participation positively influences the level of use of the budget for the purposes of performance evaluation and contributes to the development of budgetary knowledge of managers; these results are similar to those of Zonatto, Weber, and Nascimento (2019).

This evidence shows that budgetary participation may be able to act for the qualification of budget management processes in organizations. Through this, it becomes possible to align resources with budgetary objectives and goals, mobilizing the managers' cognitive and personal factors, in order to achieve the achievement of better performance, as demonstrated by Shields and Shields (1998) and Subramaniam and Ashkanasy (2001). Managers involved in the budgeting process are more likely to share information (Merchant, 2007). Consequently, they present better managerial attitudes towards the budget, showing themselves to be more satisfied and involved with the work. In these conditions, they are more likely to have better managerial performance, which tends to reflect positively on better organizational performance (Chenhall \& Brownell, 1988; Jermias \& Yigit, 2013).
The results found also reveal that managerial attitudes are positively associated with the hierarchical level of the function, which suggests that a higher hierarchical level enhances the managerial attitudes of managers. In this condition, managers tend to have a higher level of job satisfaction and better managerial performance. This occurs when there is budgetary participation and the budget is used for performance evaluation purposes, as proposed by Dunk (1992).

Regarding the demographic variables of age and genre, the results provide evidence of a higher level of budgetary participation by younger managers. In the sample analyzed, male managers showed a higher level of budgetary participation, while female managers showed lower levels of managerial attitudes and performance.

In summary, it can be seen that the participatory budget configuration has a direct and indirect influence on management performance, through the mobilization of cognitive and personal resources, determinants of action and human development at work, as demonstrated in the studies by Lunardi, Zonatto, and Nascimento (2020). Therefore, it appears that, under these conditions, the adoption of participatory budget management practices will produce positive effects on individuals at work (Jacomossi et al., 2018; Degenhart et al., 2019; Lunardi et al., 2020).

\section{CONCLUSION AND RECOMMENDATIONS}

This study investigated the effects of budgetary participation on managerial attitudes, job satisfaction, and managerial performance with a sample of 316 controllers from Brazilian companies with budget responsibility. Descriptive research was performed through survey and quantitative approach of data. 
The results indicated that among the investigated controllers the level of budgetary participation and managerial performance differ. In investigating managerial attitudes, controllers reported believing that budgeting makes them better managers. However, it is less often identified that budgeting can make them more flexible and innovative individuals. Analyzing the satisfaction of the controllers investigated, the results indicated that the work causes personal satisfaction, but less frequently the satisfaction is caused by the budgetary participation.

When testing the research hypotheses, it was found that $(\mathrm{H} 1)$ there is a positive and significant relationship between budgetary participation and managerial performance; this suggests that, according to the respondent controllers of this research, participation in the budgeting process influences their performance as a manager in their work activities. It was also found that (H2) there is a positive and significant relationship between budgetary participation and managerial attitudes at work and that (H3) there is a positive and significant relationship between budgetary participation and job satisfaction. Thus, it can be identified that the attitudes of the respondent controllers of the survey, which were investigated through the variables of managerial attitudes and job satisfaction, are directly influenced by the participation of controllers in the budgeting process.

These attitudinal variables were also investigated as mediators of the relationship between budgetary participation and managerial performance, in which (H4) managerial attitudes and (H5) job satisfaction mediate the relationship between budgetary participation and managerial performance. The results found that management performance is affected by the joint effect of budgetary participation with management attitudes. Participation in budgeting processes improves controllers' managerial attitudes and job satisfaction, positively and indirectly affecting the managerial performance of these managers.

The evidence found in this study allows us to conclude that budgetary participation influences attitudes (managerial attitudes and job satisfaction) and managerial performance. Evidence indicates that the effects of budgetary participation on managerial performance occur directly and indirectly, when mediated by the variables of managerial attitudes and job satisfaction. These findings reinforce the informative roles of the budget, as well as its cognitive, motivational, and achievement value effects.

Individuals have a self-referential cognitive system that allows them to make decisions that they judge, in that context of social interaction, as the most appropriate. By actively participating in their organizations' budget processes and realizing their influence on their unit's budget, they become more committed to the organization, developing proactive management attitudes, and believing that budgeting can make them better managers. Consequently, they tend to be more satisfied with their work, and are willing to make greater efforts to develop their work activities, which will positively reflect on their performance and organizational performance, based on the achievement of established goals and targets.

These findings reveal important practical and social implications for organizational management, since they show under what conditions budgetary participation can positively influence controllers' managerial attitudes, job satisfaction, and managerial performance. They reveal how organizational managers can create a favorable budget environment that can positively influence the behavior of individuals at work through the adoption of a participatory budget setting.

Likewise, they reinforce the evidence of the need to understand the interactionist effects of variables present in the budget context. Analysis of direct relations may indicate whether or not there is a relationship between certain variables. However, the joint observance of direct and indirect effects allows a better understanding of existing interactions and their influences and reflections on performance. Such findings may contribute to building a more solid knowledge of the effects of participation on performance.

The findings also reveal that the budget continues to be used by several organizations as an important organizational planning and control instrument, being used for management performance evaluation purposes. They also indicate that controllers, in their work activities, are evaluated by the budget forecasts established for their units of responsibility. In this way, they allow these professionals to understand the effects of (differentiated) levels of budgetary participation in their work activities. By motivating and assisting subordinates in their work performance, budgetary participation tends to contribute to the improvement of the organization's management processes, as well as the improvement of the work environment, which tends to positively impact the performance of other employees of the organization.

Of course, the study has limitations. Due to the complexity of the cognitive responses of individuals, the adoption and use of control instruments can produce distinct effects on human behavior, being subject to effects of other intervening variable not investigated in this research. However, these findings provide new evidence that encourages 
further studies. In this sense, as recommendations of future studies, it is appropriate to investigate the variables that may negatively influence management performance, such as stress situations, bornout, as well as other variables that are able to mediate this relationship.

Situational constraints may also constitute a research opportunity for further studies. Analyzing the interactionist effects of commitment,

\section{REFERENCES}

Argyris, C. (1952). The impact of budgets on people: a study prepared for the controllership foundation. Ithaca; New York: Cornell University.

Avey, J. B., Nimnicht, J. L., \& Pigeon, N. G. (2010). Two field studies examining the association between positive psychological capital and employee performance. Leadership \& Organization Development Journal, 31(5), 384-401. http://doi. org/10.1108/01437731011056425

Bagozzi, R. P., \& Phillips, L. W. (1982). Representing and testing organizational theories: a holistic construal. Administrative Science Quarterly, 27(3)459-489. http:// doi.org/10.2307/2392322

Bandura, A. (1977). Social learning theory. Englewood Cliffs, N.J.: Prentice-Hall.

Birnberg, J. G., Luft, J., \& Shields, M. D. (2007). Psychology theory in management accounting research. Handbooks of Management Accounting Research, 1, 113-135. https:// doi.org/10.1016/S1751-3243(06)01004-2

Brownell, P. (1982). The role of accounting data in performance evaluation, budgetary participation, and organizational effectiveness. Journal of Accounting Research, 20(1), 12-27. http://doi.org/10.2307/2490760

Brownell, P. (1983). Leadership style, budgetary participation and managerial behavior. Accounting, Organizations and Society, 8(4), 307-321. https://doi.org/10.1016/03613682(83)90046-6

Brownell, P., \& Mcinnes, M. (1986). Budgetary participation, motivation, and managerial performance. Accounting Review, 61(4), 587-600.

Brownell, P., \& Dunk, A. S. (1991). Task uncertainty and its interaction with budgetary participation and budget emphasis: some methodological issues and empirical investigation. Accounting, Organizations and Society, 16(8), 693-703. https://doi.org/10.1016/03613682(91)90020-F

Byrne, S., \& Damon, F. (2008). To participate or not to participate? Voice and explanation effects on performance in a multi-period budget setting. The British Accounting Review, 40(3), 207-227. https://doi.org/10.1016/j. bar.2008.04.001 involvement, and motivation for work can also indicate under what conditions individual dedication mitigates the negative effects of occupational stress or environmental stresses. The same can be observed from the effects of other cognitive and behavioral variables that can be used when conducting new intervening studies, such as the psychological capacities of individuals and their personal resilience.

Chenhall, R. H., \& Brownell, P. (1988). The effect of participative budgeting on job satisfaction and performance: Role ambiguity as an intervening variable. Accounting, Organizations and Society, 13(3), 225-233. https://doi. org/10.1016/0361-3682(88)90001-3

Chong, V. K. (2002). A note on testing a model of cognitive budgetary participation processes using a structural equation modeling approach. Advances in Accounting, 19, 27-51. https://doi.org/10.1016/S08826110(02)19003-1

Chong, V. K., \& Chong, K. M. (2002). Budget goal commitment and informational effects of budget participation on performance: a structural equation modeling approach. Behavioral Research in Accounting, 14(1), 6586. https://doi.org/10.2308/bria.2002.14.1.65

Chong, V. K., Eggleton, I. R. C., \& Leong, M. K. C. (2005). The impact of market competition and budgetary participation on performance and job satisfaction: a research note. The British Accounting Review, 37(1), 115-133. https://doi. org/10.1016/j.bar.2004.06.007

Chong, V. K., \& Johnson, D. M. (2007). Testing a model of the antecedents and consequences of budgetary participation on job performance. Accounting and Business Research, 37(1), 3-19. https://doi.org/10.108 0/00014788.2007.9730055

Covaleski, M., Evans III, J. H., Luft, J., \& Shields, M. D. (2007). Budgeting research: three theoretical perspectives and criteria for selective integration. In Chapman, C. S., Hopwood, A. G., \& Shields, M. D. Handbook of Management Accounting Research (Vol. 2, Chap. 6, pp. 587-624). [Amsterdam]: Elsevier Science.

Dani, A. C., Zonatto, V. C. S., \& Diehl, C. A. (2017). Participação orçamentária e desempenho gerencial: uma meta-análise das relações encontradas em pesquisas desenvolvidas na área comportamental da contabilidade. Advances in Scientific and Applied Accounting, 10(1), 54-72. http:// doi.org/10.14392/ASAA.2017100104

Degenhart, L., Lunardi, M. A., \& da Silva Zonatto, V. C. (2019). Antecedentes que determinam os níveis de Participação Orçamentária e seus efeitos na Assimetria de Informação e Desempenho Gerencial. Contabilidade Vista \& Revista, 30(2), 22-51. https://doi.org/10.22561/ cvr.v30i2.4742. 
Derfuss, K. (2009). The relationship of budgetary participation and reliance on accounting performance measures with individual-level consequent variables: a metaanalysis. European Accounting Review, 18(2), 203-239. http://doi.org/ 10.1080/09638180802652371

Derfuss, K. (2016). Reconsidering the participative budgetingperformance relation: A meta-analysis regarding the impact of level of analysis, sample selection, measurement, and industry influences. The British Accounting Review, 48(1), 17-37. https://doi. org/10.1016/j.bar.2015.07.001

Dewar, R., \& Werbel, J. (1979). Universalistic and contingency predictions of employee satisfaction and conflict. Administrative Science Quarterly, 24(3), 426-448.

Dunk, A. S. (1989). Budget emphasis, budgetary participation and managerial performance: a note. Accounting, Organizations and Society, 14(4), 321324. https://doi.org/10.1016/0361-3682(89)90002-0

Dunk, A. S. (1992). The effects of managerial level on the relationship between budgetary participation and job satisfaction. The British Accounting Review, 24(3), 207218. https://doi.org/10.1016/S0890-8389(05)80020-4

Frezatti, F. (2009). Orçamento Empresarial. $5^{\text {th }}$ ed. São Paulo: Atlas.

Frucot, V., \& Shearon, W. T. (1991). Budgetary participation, locus of control, and Mexican managerial performance and job satisfaction. Accounting Review, 66(1), 80-99.

Hair Jr., J. F., Babin, B. J., Money, A. H., \& Samouel, P (2005). Fundamentos de Métodos de Pesquisa em Administração. Porto Alegre: Bookman.

Hair Jr., J. F., Babin, B. J., Money, A. H., \& Samouel, P (2009). Análise multivariada de dados. $5^{\text {th }}$ ed. Porto Alegre: Bookman, 2009.

Hannan, R. L., Rankin, F. W., \& Towry, K. L. (2010). Flattening the organization: the effect of organizational reporting structure on budgeting effectiveness. Review of Accounting Studies, 15(3), 503-536.

Jacomossi, F., Schlup, D., \& Zonatto, V. C da S. (2018). Efeitos da participação orçamentária na relação entre ambiguidade e conflito de papéis e o desempenho gerencial. Advances in Scientific \& Applied Accounting, 11(3). http://doi. org/10.14392/ASAA.2018110302

Jermias, J., \& Yigit, F. (2013). Budgetary participation in Turkey: the effects of information asymmetry, goal commitment, and role ambiguity on job satisfaction and performance. Journal of International Accounting Research, 12(1), 29-54. http://doi.org/10.2308/jiar-50385

Karakoc, E. Y., \& Ozer, G. (2016). An investigation of BudgetRelated Antecedents of Job Performance. International Journal of Research in Business and Social Science, 5(3), 38-53. https://doi.org/10.20525/ijrbs.v5i3.165

Kenis, I. (1979). Effects of budgetary goal characteristics on managerial attitudes and performance. The Accounting Review, 54(4), 707-721. http://doi.org/10.1109/ ICMSS.2010.5578521
Kyj, L., \& Parker, R. J. (2008). Antecedents of budget participation: leadership style, information asymmetry, and evaluative use of budget. A Journal of Accounting, Finances and Business Studies, 44(4), 423-442. https:// doi.org/10.1111/j.1467-6281.2008.00270.x

Lau, C., \& Buckland, C. (2001). Budgeting - the role of trust and participation: a research note. Abacus, 37(3), 369-388. https://doi.org/10.1111/1467-6281.00092

Lau, C. M., Low, L. C., \& Eggleton, I. R. C. (1997). The interactive effect of budget emphasis, participation and task difficulty on managerial performance: a cross-cultural study. Accounting, Auditing and Accountability Journal, 10(2), 175-197. http://doi. org/10.1108/09513579710166712

Lavarda, C. E. F., \& Almeida, D. M. (2013). Participação orçamentária e assimetria informacional: um estudo em uma empresa multinacional. Brazilian Business Review, 10(2), 74-96. http://dx.doi.org/10.15728/ bbr.2013.10.2.4

Lavarda, C. E. F., \& Fank, O. L. (2014). Relação da assimetria da informação, da participação orçamentária e do risco na criação da folga orçamentária. Contextus, 12(1), 81-110. https://doi.org/10.19094/contextus.v12i1.32172

Libby, T., \& Lindsay, R. M. (2010). Beyond budgeting or budgeting reconsidered? A survey of North-American budgeting practice. Management Accounting Research, 21(1), 5675. https://doi.org/10.1016/j.mar.2009.10.003

Lunardi, M. A., Zonatto, V. C. D. S., \& Nascimento, J. C. (2020). Efeitos cognitivos mediadores do compartilhamento de informação na relação entre participação orçamentária e desempenho gerencial. Revista Contabilidade \& Finanças, 31(82), 14-32. https://doi.org/10.1590/1808$057 \times 201908610$

Mahoney, T. A., Jerdee, T. H., \& Carroll, S. J. (1963). Development of managerial performance: a research approach. Cincinnati, OH: South-Western.

Mahoney, T. A., Jerdee, T. H., \& Carroll, S. J. (1965). The job(s) of management. Industrial Relations, 4(2), 97-110. https:// doi.org/10.1111/j.1468-232X.1965.tb00922.x

Merchant, K.A. (1981). The design of corporate budgeting systems: influences of managerial behavior and performance. The Accounting Review, 56(4), 813-829. Retrieved from: https://www.jstor.org/stable/247203?seq=1

Merchant, K. A. (2007). O modelo do sistema de orçamento corporativo: influências no comportamento e no desempenho gerencial. Revista de Contabilidade $e$ Organizações, 1(1), 107-124. https://doi.org/10.11606/ rco.v1i1.34700

Mia, L. (1988). Managerial attitude, motivation and the effectiveness of budget participation. Accounting, Organizations and Society, 13(5), 465-475. https://doi.org/10.1016/03613682(88)90017-7

Milani, K. (1975). The relationship of participation in budgetsetting to industrial supervisor performance and attitudes: a field study. The Accounting Review, 50(2), 274-284. Retrieved from: https://www.jstor.org/ stable/244709?seq=1 
Nouri, H., \& Parker, R. J. (1998). The relationship between budget participation and job performance: the roles of budget adequacy and organizational commitment. Accounting Organizations and Society, 23(5-6), 467-483. https:// doi.org/10.1016/S0361-3682(97)00036-6

Oro, I. M., Beuren, I. M., \& Carpes, A. M. da S. (2014). Competências e habilidades exigidas do controller e a proposição para sua formação acadêmica. Contabilidade Vista \& Revista, 24(1), 15-36. Retrieved from: https://revistas.face. ufmg.br/index.php/contabilidadevistaerevista/article/ view/593

Parker, R. J., \& Kyj, L. (2006). Vertical information sharing in the budgeting process. Accounting, Organizations and Society, 31(1), 27-45. https://doi.org/10.1016/j. aos.2004.07.005

Ribeiro, L. M. S., Lunkes, R. J., Schnorrenberger, D., \& Gasparetto, V. (2011). Perfil do Controller em empresas de médio e grande porte da Grande Florianópolis. Revista Catarinense da Ciência Contábil, 7(20), 57-70. http:// dx.doi.org/10.16930/2237-7662/rccc.v7n20p57-70

Rodrigues, A. (1986). Psicologia Social. $11^{\text {st }}$ ed. Petrópolis: Vozes.

Santos, A. C. D., Lavarda, C. E. F., \& Marcello, I. E. (2014). The relationship between cost management knowledge and budgetary participation with managers' performance. Revista Brasileira de Gestão de Negócios, 16(50), 124-142. http://doi.org/10.7819/ rbgn.v16i50.1236

Schermerhorn Jr., J. R., Hunt, J. G., \& Osborn, R. N. (2007). Fundamentos de comportamento organizacional. $2^{\text {nd }}$ ed. Porto Alegre: Bookman.

Schmidt, P., \& Santos, J. L. (2006). Fundamentos de controladoria. São Paulo: Atlas.

Shields, J. F., \& Shields M. D. (1998). Antecedents of participative budgeting. Accounting, Organizations and Society, 23(1), 49-76. https://doi.org/10.1016/S0361-3682(97)00014-7

Subramaniam, N., \& Ashkanasy, N. M. (2001). The effect of organisational culture perceptions on the relationship between budgetary participation and managerial job-related outcomes. Australian Journal of Management, 26(1), 35-54. https://doi. org/10.1177/031289620102600103
Subramaniam, N., \& Mia, L. (2001). The relation between decentralised structure, budgetary participation and organisational commitment: the moderating role of managers' value orientation towards innovation. Accounting, Auditing \& Accountability Journal, 14(1), 12-30. http://doi. org/10.1108/09513570110381051

Wong-On-Wing, B., Guo, L., \& Lui, G. (2010). Intrinsic and extrinsic motivation and participation in budgeting: antecedents and consequences. Behavioral Research in Accounting, 22(2), 133-153. http://doi.org/10.2308/ bria.2010.22.2.133

Young, S. M. (1985). Participative budgeting: The effects of risk aversion and asymmetric information on budgetary slack. Journal of Accounting Research, 23(2), 829-842. Retrieved from: https://www.jstor.org/ stable/2490840?seq=1

Zainuddin, Y., Yahya, S., Kader Ali, N. N., \& Abuenniran, A. S. (2008). The consequences of information asymmetry, task and environmental uncertainty on budget participation: evidence from Malaysian managers. International Journal Managerial and Financial Accounting, 1(1), 97114. http:/doi.org/10.1504/IJMFA.2008.020464

Zonatto, V. C. S. (2014). Influência de fatores sociais cognitivos de capacidade, vontade e oportunidade sobre o desempenho gerencial nas atividades orçamentárias das maiores empresas exportadoras do Brasil. (Tese de Doutorado). Universidade Regional de Blumenau, Blumenau, SC, Brasil.

Zonatto, V. C. S., \& Lavarda, C. E. F. (2013). Evidências dos efeitos da participação orçamentária na assimetria de informação, estresse ocupacional e desempenho no trabalho. Advances in Scientific and Applied Accounting, 6(1), 92-111. doi.org/10.14392/ASAA.2018110302

Zonatto, V. C. S., Weber, A., \& Nascimento, J. C. (2019). Effects of budgetary participation on asymmetry of information, occupational stress and managerial performance. Revista de Administração Contemporânea, 23(1), 67-91. http:// dx.doi.org/10.1590/1982-7849rac2019170327 


\section{Authorship}

\section{Vinícius Costa da Silva Zonatto*}

Av. Roraima, $\mathrm{n}^{\circ}$ 1000, Cidade Universitária, CCSH, Prédio 74C, 97105-900, Santa Maria, RS, Brazil.

E-mail address: viniciuszonatto@gmail.com

(1) https://orcid.org/0000-0003-0823-6774

\section{Juliana Constâncio Nascimento}

Rua Antônio da Veiga, no 140, Itoupava Seca, 89012-500, Blumenau, SC, Brazil.

E-mail address: prof.juconstancio@gmail.com

(1) https://orcid.org/0000-0002-8661-127X

\section{Micheli Aparecida Lunardi}

Rua Antônio da Veiga, no 140, Itoupava Seca, 89012-500, Blumenau, SC, Brazil.

E-mail address: michelilunardi01@gmail.com

(ㄱ) https://orcid.org/0000-0003-0622-928X

\section{Larissa Degenhart}

Av. Roraima, no 1000, Cidade Universitária, CCSH, Prédio 74C, 97105-900, Santa Maria, RS, Brazil.

E-mail address: larissadegenhart@gmail.com

(1) https://orcid.org/0000-0003-0651-8540

* Corresponding Author

\section{Funding}

This work was financially supported by the Ministério da Ciência, Tecnologia e Inovação, Conselho Nacional de Desenvolvimento Científico e Tecnológico (grant \#472195/2014-0).

\section{Conflict of Interest}

The authors have stated that there is no conflict of interest.

\section{Copyrights}

RAC owns the copyright to this content.

\section{Plagiarism Check}

The RAC maintains the practice of submitting all documents approved for publication to the plagiarism check, using specific tools, e.g.: iThenticate.

\section{Author's Contributions}

$\mathbf{1}^{\text {st }}$ author: conceptualization (equal); formal analysis (equal); funding acquisition (lead); investigation (lead); methodology (equal); project administration (lead); resources (lead); supervision (lead); writing-review \& editing (lead).

$2^{\text {nd }}$ author: conceptualization (equal); data curation (lead); formal analysis (equal); investigation (equal); methodology (equal); writing-original draft (lead).

$3^{\text {rd }}$ author: conceptualization (equal); data curation (lead); formal analysis (equal); investigation (equal); methodology (equal); writing-original draft (lead).

$4^{\text {th }}$ author: conceptualization (equal); formal analysis (equal); methodology (equal); writing-original draft (equal).

\section{Peer Review Method}

This content was evaluated using the double-blind peer review process. The disclosure of the reviewers' information on the first page is made only after concluding the evaluation process, and with the voluntary consent of the respective reviewers.

\section{Data Availability}

According to the authors, they will not share their database, and claim that they do so in view of the fact that: as ethical procedures adopted when collecting the data necessary to carry out this research, the participants were told that the collected data would not be disclosed, being treated statistically and in a consolidated manner. On this occasion, participants were also assured that only the consolidated statistical results of the research would be disseminated for academic purposes, and this information would be presented through tables, figures and/or charts. According to the authors, this is the reason they will not share their database.

RAC encourages data sharing but, in compliance with ethical principles, it does not demand the disclosure of any means of identifying research subjects, preserving the privacy of research subjects. The practice of open data is to enable the reproducibility of results, and to ensure the unrestricted transparency of the results of the published research, without requiring the identity of research subjects. 